ppi $201502 Z U 4645$

Esta publicación científica en formato digital es continuidad de la revista impresa ISSN-Versión Impresa 0798-1406 / ISSN-Versión on line 2542-3185Depósito legal pp $197402 Z$ U34

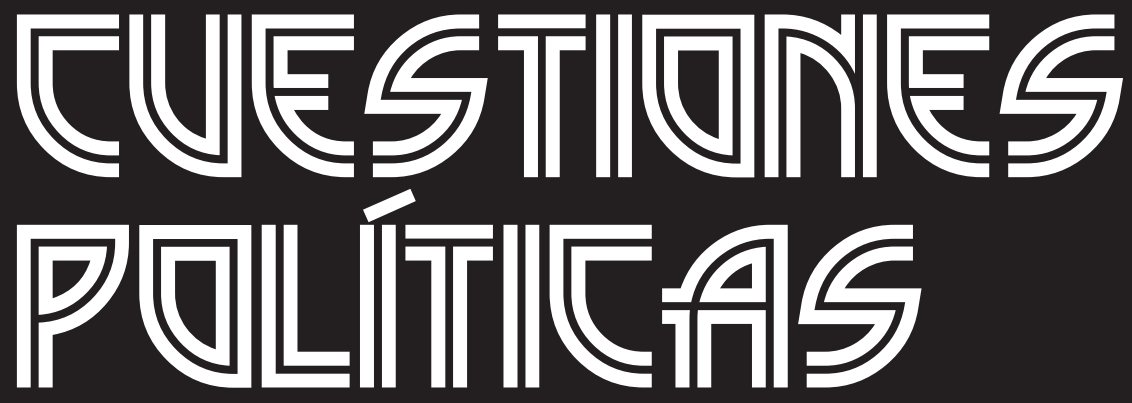

Instituto de Estudios Políticos y Derecho Público "Dr. Humberto J. La Roche" de la Facultad de Ciencias Jurídicas y Políticas de la Universidad del Zulia Maracaibo, Venezuela
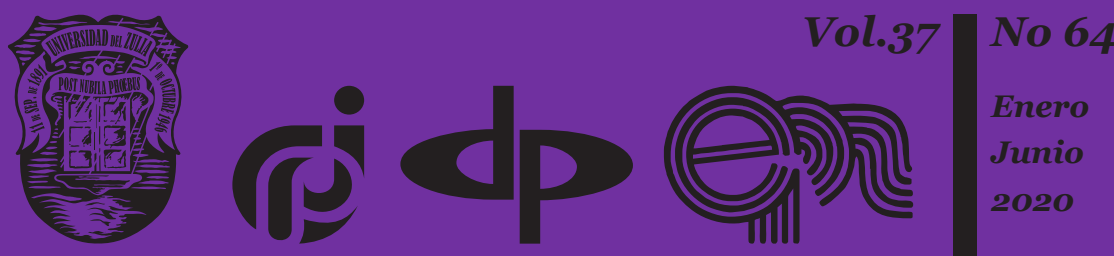


\title{
Legal Impact Theory in the Context of an Integrative Approach to Understanding Law
}

\author{
Roman R. Palekha* \\ Valery P. Belyaev ** \\ Valery P. Kanishchev *** \\ Larisa L. Solovyova **** \\ Neonila A. Turanina *****
}

\begin{abstract}
The theory of legal impact from the perspective of an integrative approach to understanding law, is a progressive theoretical and methodological toolkit with a high potential of heuristically mastering of various legal phenomena. This theory understood within the framework of an integrative approach, allows us to consider its legal nature, content and essence as fully and thoroughly as possible, which creates favorable conditions for achieving the criteria of scientific research, such as: comprehensiveness, objectivity, and historicism. It is the integrative approach that makes it possible to fully realize such a fundamental principle of scientific research as unity in diversity, to study the nature of the legal impact comprehensively and deeply, as a complex socio-legal phenomenon, determined by various factors of public life. The methodological ground of the examination depends on the utilization of different general logical procedures and techniques for logical information, just as specific logical strategies - recorded legitimate, formallawful, relative lawful and interpretative. Results showed that law isn't reducible to the arrangement of lawful standards, it is a lot more extensive and progressively various, which is related with its source, bearer and vehicle - a man, with his intentionally solid willed nature and passionate
\end{abstract} mental motivations.

* PhD in Law, The Russian State University of Justice (The Central branch of The Russian State University of Justice (the city of Voronezh), 95 20-letiya Oktyabrya, Voronezh, 394006, Russia. Email: paleharr@mail.ru.

** Doctor of Law, Southwest State University, 9450 years of October Street, Kursk, 305040, Russia. Email : belvp46@mail.ru.

*** PhD in Law, The Russian State University of Justice (The Central branch of The Russian State University of Justice (the city of Voronezh), 95 20-letiya Oktyabrya, Voronezh, 394006, Russia. Email: kanishhev1953@mail.ru.

**** PhD in Law, The Russian State University of Justice (The Central branch of The Russian State University of Justice (the city of Voronezh), 95 20-letiya Oktyabrya, Voronezh, 394006, Russia. E-mail: solol1974@mail.ru.

****** Doctor of Philology, Belgorod State Institute of Arts and Culture, 7 Koroleva St., Belgorod, 308033, Russia. Email: turanina@mail.ru.

Recibido: 12/04/2019.

Aceptado: 11/06/2019. 
Roman R. Palekha, Valery P. Belyaev, Valery P. Kanishchev, Larisa L. Solovyova y Neonila A. Turanina

Keywords: legal impact; legal impact theory; integrative approach; progressive type of legal thinking; understanding of law.

\section{Teoría del impacto legal en el contexto de un enfoque integrador para comprender el derecho}

\section{Resumen}

La teoría del impacto legal desde la perspectiva de un enfoque integrador para comprender el derecho, es una herramienta teórica y metodológica progresiva con un alto potencial de dominio heurístico de varios fenómenos legales. Esta teoría, entendida en el marco de un enfoque integrador, nos permite considerar su naturaleza jurídica, contenido y esencia de la manera más completa y exhaustiva posible, lo que crea condiciones favorables para alcanzar los criterios de investigación científica, tales como: exhaustividad, objetividad e historicismo. Es el enfoque integrador que hace posible realizar plenamente un principio tan fundamental de la investigación científica como la unidad en la diversidad, estudiar la naturaleza del impacto legal de manera integral y profunda, como un fenómeno socio-legal complejo, determinado por varios factores del público. Vida. El fundamento metodológico del examen depende de la utilización de diferentes procedimientos y técnicas lógicas generales para la información lógica, al igual que las estrategias lógicas específicas: registradas como legítimas, formales, relativas, legales e interpretativas. Los resultados mostraron que la ley no es reducible a la disposición de estándares legales, es mucho más extensa y progresivamente variada, lo que está relacionado con su fuente, portador y vehículo: un hombre, con su naturaleza intencionalmente sólida y motivaciones mentales apasionadas.

Palabras clave: impacto legal; teoría Del impacto legal; enfoque integrador; tipo progresivo de pensamiento legal; comprensión Del derecho.

\section{Introduction}

Before starting to consider the theory of legal impact through the prism of an integrative approach to understanding law, as a theoretical and methodological method of scientific research, it is necessary to determine the conceptual and categorical apparatus. So, first of all, we would like to draw attention to such a concept as theory, which is understood by us as 
a significant research classification unit, distinguished by its completed character and combining various teachings, ideas, ideas about a particular phenomenon being studied. This association became possible solely on the basis of established similar essential features of the phenomenon under study and their justification as such in the scientific works of Russian and foreign law researchers.

The legal impact in the framework of the integrative approach is understood in an extremely broad context as the influence of the totality of legal tools and other general social phenomena on social life, consciousness and behavior of people.

This approach allows us to consider the legal impact as a complex sociolegal phenomenon, to explore its nature, content and essence in order to deeply understand its role in social regulation.

There is no doubt that the legal impact is a socio-legal phenomenon that creates rich soil for prospective theoretical research, but which is especially valuable, also has significant applied potential, reveals the mechanism and nature of the transformative impact of law, the totality of legal and social phenomena on social practice.

\section{Methodology}

The methodological ground of the study is based on the application of various general scientific techniques and methods of scientific knowledge (analysis, synthesis, deduction, induction, system-structural, formallogical approaches), as well as particular scientific methods - historicallegal, formal-legal, comparative-legal and interpretative.

\section{Discussion and Results}

It is proposed to begin the study of the subject of the ongoing research with the question of what is law being central in the general theory of law; the answer to it is very difficult for a number of reasons, both objective and subjective. So, even I. Kant wrote: "This question can also confuse the jurist, as the notorious question - "What is the truth?", asking the teachers of Logic" (Kant, 1988).

It should be noted that both Russian law researchers and their foreign colleagues, who draw up their ideas on the understanding of law in the form of various scientific areas, and legal understanding approaches, are in the state of permanent search for an answer to this question. 
Roman R. Palekha, Valery P. Belyaev, Valery P. Kanishchev, Larisa L. Solovyova y Neonila A. Turanina

We draw attention to the fact that the phrase that has become familiar and firmly entrenched in the scientific field "integrative legal understanding" (in our study, an integrative approach to understanding law) is a very complex, heterogeneous and ambiguous assessment tool, which has a rich history of its formation and development both in world of legal thought and in domestic legal doctrine. For the first time, the term integrative legal understanding was introduced in 1947 by the American professor Jerome Hall, who proposed considering law through a synthesis of positive law with natural-legal views (Hall, 1964).

Legal issues in their variants and aspects were addressed by such scholars of law as E. Erlich (Ehrlich, 1929), who laid the foundation for sociological jurisprudence, D. Austin (Austin, 1873), the founder of legism, G. Kelsen (Kelsen, 2007), who proposed an original scientific view in the form of a "pure doctrine of law." The achievements of all these scientists to one degree or another were taken into account within the framework of an integrative approach to understanding law, aimed at creating universal tools capable of a deep and holistic perception of law, and, therefore, creating conditions for a comprehensive knowledge of the legal phenomenon under study, that is the legal impact.

The ideas of integrative legal understanding have been intensively developed in Western legal thought, which is associated with such researchers of law as: J. Hall (Hall, 1964), I. B. Flores (Flores, 2012), H. J. Berman (Berman, 1988), J. Piaget (Piage, 1971).

Acquaintance with the works of foreign jurists allows us to state that Western legal thought follows the path of recognizing the plurality of approaches to understanding law and does not seek to create a universal understanding of it. The task of the integrative approach is not to destroy the diversity of views, but to create a dialogue reconciliation environment for them, in which there is a place for each scientific position, which will provide a broad view of the law and will allow it to see a new quality of a holistic social and legal regulator of public relations.

Applying an integrative approach to the subject of our study, it should be noted that it acts as an effective theoretical and methodological toolbox capable of a deep and comprehensive analysis of legal impact.

It seems appropriate to proceed to consider the problems associated with the study of legal impact. So, analyzing the main epistemological problems that arise before the researcher as a result of knowledge of the legal impact system L.N. Berg reasonably identifies the following:

- The limitations of the applied scientific and educational tools developed to date by representatives of the theory of state and law; 
- The problem of the fundamental principle, brick, the elementary particle of the legal impact system has not been solved;

- The existence of a narrowly oriented, linear research program of knowledge of law, defined by the formal-legal type of thinking of legal scholars;

- The problem of applying and using the principle of historicism, i.e. cognitive approach to legal impact as a historically forming and developing whole;

- The problem of the vicious circle of knowledge of the legal impact system (Berg, 2018).

The indicated problems are obvious methodological in nature and point to a certain crisis of modern legal science in the development of objective ideas about the system of legal influence, which was largely generated by the traditions of positivistic legal understanding. It seems that a productive solution to this problem is possible within the framework of an integrative approach to understanding law, which acts as a progressive type of legal thinking, which is the central theoretical and methodological category of legal theory and an effective research tool for understanding the essence of law and legal impact.

In favor of the fact that the integrative approach should be considered as a progressive type of legal thinking, the following factors can be indicated. Firstly, an integrative approach to understanding law is a type of legal thinking that best meets the needs of the modern period of development of legal relations and institutions, which is capable of reflecting comprehensively and objectively really occurring legal processes at the doctrinal level. Secondly, an integrative approach to understanding law acts as a way to resolve the methodological crisis of modern legal science. Thirdly, this type of legal thinking allows comprehensively, fully and objectively to reflect the multifaceted nature of law, integrative in nature. Fourth, an integrative understanding of law greatly expands the possibilities for effective legal regulation and protection of the most important areas of public life through a broad understanding of the forms of law. Fifth, the type of legal thinking under consideration presupposes a presumption of the relative lack of legal nature. Sixth, an integrative approach to understanding law has significant transformative capabilities that form its creative social resource (Kanishchev \& Palekha, 2018).

O.Yu. Perov justifiably notes that "the study of the role of legal understanding in legal impact is important from the standpoint of the fact that legal understanding is fundamental in the perception and knowledge of the law and its impact by a person" (Perov, 2008). 
Roman R. Palekha, Valery P. Belyaev, Valery P. Kanishchev, Larisa L. Solovyova y Neonila A. Turanina

106 Legal Impact Theory in the Context of an Integrative Approach to Understanding Law

From the above essential characteristics of law proposed within the framework of an integrative approach, the complex, multifaceted, immanently inherent and naturally determined integrative nature of law can be clearly seen. Characterizing an integrative approach to understanding law, M.V. Nemytina notes that: "Adherents of various scientific concepts are gradually coming to a common idea about the need for some kind of integral legal understanding, within the framework of which "law is considered as a system value". Their views agree that it is not necessary to contrast the types of legal understanding, but they should look for points of contact. Concepts born within the framework of one type of understanding of the law must perceive ideas developed within the framework of others and, in turn, enrich other types of legal understanding with their ideas ... It is the integral (or integrative) legal understanding that allows to form a holistic view of the law, to consider the law in a variety of manifestations and at the same time in its unity" (Nemytina, 2007).

In understanding the legal impact, based on an integrative theoretical and methodological interpretation of legal phenomena, it becomes clear that law is not reducible to the system of legal norms, it is much wider and more diverse, which is associated with its source, carrier and vehicle - a man, with his consciously strong-willed nature and emotional-psychological impulses. In substantiating this position, it seems possible to cite the observations made by V.N. Kornev, who, referring to the consideration of the categories of certainty and uncertainty of law, came to the conclusion that scientists are trying to explore these categories using methodological tools of more inherent formal dogmatic jurisprudence, which inevitably generates research errors. For example, researchers proceed from the premise of identifying existing positive (written) law and law as a phenomenon of the human mind and will, due to the material, value and historical conditions of society (Kornev, 2018).

In this regard, it must be noted that if, for the positivistic methodology based on the canons of formal dogmatic jurisprudence, the legal impact is identical to the impact of law (a system of formal legal sources of law), then within the framework of the integrative methodology, the legal impact cannot be reduced only to the impact formal legal sources of the right to public relations, but it is necessary to perceive it as a complex and holistic system of managing the formation and activities of people which integrates all the mechanisms of social rights and the functioning of links (forward and reverse) communication procedures with its direct object. the person (Orzikh, 1978).

Based on this theoretical and philosophical message of understanding the legal impact, it is difficult to disagree with the statement of M.F. Orzikha, that: "Legal influence plays the role of a logical synthesis of categories of legal formation (since the material conditionality of law includes social relations as a potential object of the ultimate goals of the impact), the nature and content 
of law (since they practically coincide with the content of the impact), the structure of law (since structural features of law determine the organization of legal means of influence). Legal impact is a complex and holistic system of managing the formation and activities of people, which integrates all the mechanisms of the social functioning of law and connects (direct and feedback) the law with its immediate object - the person" (Orzikh, 1978).

The proposed understanding of the legal impact is formulated in the mainstream of an integrative methodology based on interdisciplinary and synergetic approaches that consider this legal phenomenon as a complex socio-legal complex of an objective-subjective nature determined by the material conditions of society.

It should be noted that the legal impact is always different in directional nature, has its own vector, which depends on the objectives pursued. So, to ensure state sovereignty, national security acts as a priority goal (Belyaeva et $a l, 2019$ ), based on the provisions of fundamental state-forming documents. For the United States, these are documents responsible for the formation of the National Security Strategy, such as the Declaration of Independence (The Declaration of Independence), the US Constitution (Constitution for the United States) and the Bill of Rights (Bill of Rights). The National Security Strategy of the Russian Federation is defined by Decree of the President of the Russian Federation dated December 31, 2015 No. 683 "On the National Security Strategy of the Russian Federation" (Decree of the President of the Russian Federation of December 31, 2015).

The observations of L.N. Berg, according to which "The legal effect in essence is an ordered set of elements, and because of its quality, it is necessary to use the methodology of a systematic approach in legal studies, to use the category "system" more widely. A feature of the modern approach to considering legal impact is such that it is interdisciplinary in nature ... The systemic nature of the elements of legal influence is expressed in the fact that they all have a common feature, the ability to integrate and synergy" (Berg, 2018).

The proposed observations allowed us to conclude that the legal impact “... appears in the form of a complex, multi-level structure, manifested in the form of various legal processes, the elements of which, although they are the expression of legal statics, are completely not identical to them" (Berg, 2018).

This conclusion was confirmed in the position of V.V. Ershova: "With this general scientific approach, the interconnected and complementary processes of both law-making and the implementation of law, and the study of individual legal phenomena, including elements and forms of national and (or) international law, should occur as" moments of the whole ", i.e. not in isolation and independently, but primarily in the framework of a unified, developing and multi-level system of forms of national and (or) international law, implemented in the state" (Ershov, 2018). 
Roman R. Palekha, Valery P. Belyaev, Valery P. Kanishchev, Larisa L. Solovyova y Neonila A. Turanina

108 Legal Impact Theory in the Context of an Integrative Approach to Understanding Law

The cognitive resource of an integrative methodology that considers legal impact as a complex social and legal unit seems significant and scientifically sound, since it is based on the method of dialectics (materialist dialectics), which allows to fully achieve the criteria of scientific knowledge in the phenomenon under study: objectivity, comprehensiveness, historicism. It is necessary to identify with the convincing and scientifically sound position of L.N. Berg, “...the system of legal influence is only a limited part of legal reality, and the subject of cognition must be somehow separated from it, designated in such a way as to take into account its dual material and ideal essence. Therefore, the legal impact as an object can be studied from different sides, and each of these sides can act as a special subject of research. The dialectical approach to the problem of cognition of legal impact leads to the idea of the special relevance of the problem of forecasting the further development of the legal impact system" (Berg, 2018a).

\section{Conclusion}

At the end of the consideration of the theory of legal impact in the context of an integrative approach to understanding law, it seems possible to draw the following conclusions. Firstly, legal impact is a socio-legal phenomenon that has significant applied potential, which reveals the mechanism of legal impact on social practice, indicates the nature of transformative social impact, which inevitably reflects, and sometimes determines the degree of legal integration and legal socialization of an individual (Sinenko et al, 2019). Secondly, the legal impact is a means and mechanism of society management, which involves at the beginning the creation of a legal space through the definition of legal boundaries permitted in the rule of law, and the ideal incorporation of personality into it, and then the formation of a legal order, using all available legal means impact on personality. Thirdly, the legal impact is, first of all, the impact of legal values on social life, consciousness and human behavior in the direction of the statement of socially useful goals and the construction of a predictable and stable law and order based on them.

The most important thing is that the study of legal impact should be evaluated, first of all, from the point of the social result to which the given legal phenomenon should lead. And this, in our opinion, is the following:

1. The formation of a stable law and order ensured by a predictable and balanced law enforcement practice;

2. reliable legal protection of the interests of the individual, society and the state protected by the developed system of forms of national and international law; 
3. The practical implementation of the satisfaction of needs by legal entities in their possession of material and spiritual benefits;

4. Ensuring sustainable and progressive development of civil society and the rule of law, as well as creating comfortable legal conditions for the individual in the realization of his human potential.

\section{Bibliographic References}

AUSTIN, Joe. 1873. Lectures on Jurisprudence or the Philosophy of the positive Law. 1. London, England.

BELYAEVA, George; BELYAEV, V; BIDOVA, B; DYUMINA, A; KUKSIN, I. 2019. "Peculiarities of national interests' institutionalization in the North American tradition: history and modernity" In: Humanities \& Social Sciences Reviews. No. 7, Vol. 4, pp. 122-140.

BERG, Lyudmila Nikolay. 2018. "On the main epistemological problems of the formation of a model of legal impact” In: State and Law. No. 3, pp. 33-48 [in Russian].

BERG, Lyudmila Nikolay. 2018a. Theoretical and Legal Science of Legal Impact. Legal Issues. Collective monograph based on the results of the III Alekseevsky readings / rev. ed. V.D. Passes. - Yekaterinburg: Publishing House of the Ural State University [in Russian].

BERMAN, Jordan. 1988. "Toward an Integrative Jurisprudence: Politics, Morality, History” In: California Law Review. No. 76, Vol. 4, pp. 779-801.

BILL OF RIGHTS "An Act declaring the Rights and Liberties of the Subject and Settling the Succession of the Crown". Available online. In: http:// www.legislation.gov.uk/aep/WillandMarSess2/1/2/contents. Date of consultation: $27 / 01 / 2020$.

CONSTITUTION FOR THE UNITED STATES. 1787. Available online. In: https://www.whitehouse.gov/about-the-white-house/theconstitution/. Date of consultation: 27/01/2020.

DECREE OF THE PRESIDENT OF THE RUSSIAN FEDERATION OF DECEMBER 31, 2015 No. 683 "On the National Security Strategy of the Russian Federation" (January 4, 2016) // Collection of legislation of the Russian Federation. No. 1 (part II), Art. 212 [in Russian].

EHRLICH, Evgenevna. 1929. Grundlegung der Soziologie des Rechts. Miinchen und Leipzig. 
Roman R. Palekha, Valery P. Belyaev, Valery P. Kanishchev, Larisa L. Solovyova y Neonila A. Turanina

110

Legal Impact Theory in the Context of an Integrative Approach to Understanding Law

ERSHOV, Valery Valerievna. 2018. Legal and Individual Regulation of Public Relations: Monograph. M.: RPMU Moscow. [in Russian].

FLORES, Borisovna Ivanovna. 2012. "The Problem about the Nature of Law visà-vis Legal Rationality Revisited: Towards an Integrative Jurisprudence" In: Georgetown Public Law and Legal Theory Research Paper. No.12160, pp.1-37.

HALL, Jerome. 1964. "From Legal Theory to Integrative Jurisprudence" In: University of Cincinnati Law Review. No. 33, Vol. 2, pp. 153-205.

KANISHCHEV Valery Pavel; PALEKHA, R.R. 2018. "An Integrative Approach to Understanding Law as a Progressive Type of Legal Thinking" In: Bulletin of the Voronezh Institute of the Ministry of Internal Affairs of Russia. - Voronezh, 2, pp. 88-112. [in Russian].

KANT, Immanuel. 1988. Rechtslehre: Schriften zur Rechtsphilosophie. Berlin, Germany. 34 p.

KELSEN, Hans. 2007. General Theory of Law and State. The lawbook Exchange, Ltd, Moscow, Russia.

KORNEV, Vladimir Nikolay 2018. "Dialectics of Uncertainty and Certainty of Law” In: State and Law. No. 11, pp. 66-81 [in Russian].

NEMYTINA, Marina Valery. 2007. Problems of Improving Legal Understanding. Modern Research Methods in Jurisprudence, Ed. N.I. Matuzova and A.V. Malko. Saratov. Moscow. [in Russian].

ORZIKH, Mikaeil. 1978. Law and Personality. Kiev - Odessa [in Russian].

PEROV, Olga Yagfarovna. 2008. Dialectics of the Correlation of Legal Understanding and Legal Impact: Author. Dis Cand. Legal Sciences. Nizhny Novgorod [in Russian].

PIAGE, Joe. 1971. "Methodologie des Relation Interdisciplinaires” In: Archives de Philosophie. Recherches et documentation. No. 34, Vol. 4, pp. 540561.

SINENKO, Valery Sergei; TURANIN, V.Y; LILIKOVA, O.S; MITYAKINA, N.M; RUBANOV, S.A. 2019. "Legal regulation of public companies in the countries of the anglo-saxon legal system" In: Amazonia Investiga. No. 8. Vol. 19, pp. 679-683.

THE DECLARATION OF INDEPENDENCE. S.d. Available online. In: http:// www.ushistory.org/DECLARATION/document/. Date of consultation: 12/03/2019. 

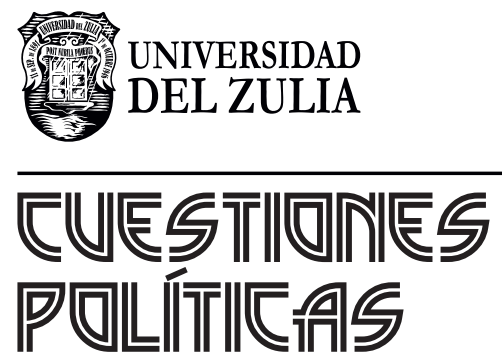

Vol. $37 \mathrm{~N}^{\circ} 64$

Esta revista fue editada en formato digital y publicada en junio de 2020, por el Fondo Editorial Serbiluz, Universidad del Zulia. Maracaibo-Venezuela 